\title{
ISZLÁM ÉS DEMOKRÁCIA INDONÉZIÁBAN: EGY KONSZENZUSORIENTÁLT MODELL FELÉ?
}

\author{
Gyene Pál \\ (Budapesti Gazdasági Egyetem Külkereskedelmi Kar) \\ A tanulmány beérkezett: 2018. október 4., opponálás: 2018. november 6. - 2019. január 4., \\ véglegesítve: 2019. január 22.
}

\begin{abstract}
ÖSSZEFOGLALÓ
Tanulmányomban a politikai demokrácia adaptálásának lehetőségeit vizsgáltam a délkelet-ázsiai, pontosabban az indonéziai iszlám kontextusában. Az „iszlám faktor” hatását az indonéz politikai rendszerre meglátásom szerint legalább három elkülönülő elemzési szinten érdemes vizsgálni: 1. a társadalom politikai tagozódásának szintjén: az iszlámhoz, illetve az állam szekuláris jellegéhez füződő viszony képezi mind a mai napig az indonéz társadalom talán legalapvetőbb politikai törésvonalát; 2 . a pártrendszer szintjén: a politikai iszlám platformján álló pártok helye és szerepe az indonéz pártrendszerben; 3 . végül, de nem utolsósorban a parlamenti politizálás szintje: a szekuláris és iszlám pártok mennyiben befolyásos alakítói a törvényhozásnak és a végrehajtó hatalom gyakorlásának. Míg az első két dimenzióban, tehát a társadalmi törésvonalként és a pártrendszer tagozódásában a mai napig tetten érhető a szekuláris és „iszlám” politikai szubkultúrák elkülönülése, addig a parlamenti politizálás kormány-ellenzék dichotómiája már nem ezt a törésvonalat tükrözi vissza. A jelenlegi kormánykoalícióban például szekuláris, tradicionalista és modernista muszlim pártok egyaránt részt vesznek és a politikai ellenzék ideológiai profilja hasonlóan vegyes képet mutat. Nézetem szerint egy sajátságosan indonéz, de bizonyos nyugati előképektől mégsem idegen „,konszenzusorientált” demokráciamodell van tehát kiformálódóban, ahol a politikai iszlám és az iszlamista pártok nem destabilizáló faktorként, hanem éppen ellenkezőleg - számos „nyugati” kereszténydemokrata párthoz hasonlóan - a demokratikus konszenzust erősítő „muszlim demokrata” erőként vannak jelen. A vizsgálat nem nélkülözi a történeti és implicite az összeghasonlító megközelítést sem, és nagyban épít Sartori immár klasszikusnak számító pártrendszer-tipológiájának, lijphardti „többségi” és „konszenzusos” demokráciamodelljére, valamint a parlamentáris és a prezidenciális kormányforma előnyeiről és lehetséges hátulütőiről folytatott úgynevezett neoinstitucionalista vita elméleti kereteire és módszertanára.
\end{abstract}

Kulcsszavak: Indonézia demokratizálódás - pártrendszer a politikai iszlám

Párhuzamosan azzal, ahogy a '90-es évek elején a huntingtoni civilizációs törésvonal-paradigma a nemzetközi kapcsolatokkal foglalkozó szakirodalom egyik legtöbbet hivatkozott toposzává vált, a demokrácia, illetve annak kul- 
turális-civilizációs beágyazottságának kérdése is egyre népszerúbb kutatási és vita témává lett. A huntingtoni paradigmában különösen az Iszlám civilizációs háttér és a politikai demokrácia kapcsolata tételeződik fel problémásként, amely talán elsősorban azzal magyarázható, hogy a demokrácia és az iszlám viszonyát vizsgáló kutatások sokáig elsősorban a közel-keleti térségre fókuszáltak. Ez a perspektíva azonban súlyosan torzító. Kétségtelen, hogy az iszlám bölcsőjének számító Közel-Kelet térségében - Tunézia és a posztszaddámi, 2011-ig szuverenitásában erősen korlátozott Irak kivételével - szinte egyáltalán nem találhatunk funkcionáló politikai demokráciákat. Ez azonban a Nyugatról importált nemzetállami modell közel-keleti átvételének nehézségeivel magyarázható, mintsem általánosságban az „iszlám” és a demokrácia összeegyeztethetetlenségével.

Ugyanakkor ma már az iszlám világ demográfiai és egyre inkább gazdasági súlypontja nem a Közel-Keleten, hanem Dél- ill. Délkelet-Ázsiában található. A világ jelenleg legnépesebb muszlim, pontosabban muszlim többségú országa Indonézia, amelyik a maga mintegy 260 milliós lakosságával napjainkban a világ harmadik legnépesebb politikai demokráciája is egyben, India és az Amerikai Egyesült Államok után (Mietzner-Aspinall, 2010: 3.), 220 milliós muszlim népessége pedig meghaladja a Közel-Kelet arab országainak muszlim összlakosságát (Nakamura, 2005: 2.)

Pedig 1998-ban a Szuharto-rezsim bukásakor aligha tûntek túl biztatónak az indonéziai demokratizálódás perspektívái. Az indonéz rendszerváltást folyamatát etnikai és vallási villongások kísérték. Hasonlóan komoly aggodalmakra adott okot a radikális politikai iszlám megerősödésének potenciális fenyegetése vagy éppen az informális politikai befolyását őrző hadsereg, amely bizonyos esetekben a háttérből szította az etnikai és felekezeti feszültségeket. Az alkotmányos intézményrendszerbe kódolva voltak a nehezen feloldható patthelyzetek a törvényhozás, és a végrehajtó hatalom letéteményeseként funkcionáló elnök között. A politikai pártok gyenge intézményesültsége és sok esetben konfúzus ideológiai profilja, valamint az arányos választási rendszer folytán igen erősen fragmentált parlamenti paletta viszonyai közepette a többségi kormányzás komoly kihívást jelent a mindenkori elnökök számára.

Azonban rácáfolva minden korábbi aggodalomra és szkeptikus várakozásra, Indonézia Szuharto bukása és az 1998-ban megkezdődött „rendszerváltás” óta immár négy parlamenti és három közvetlen elnökválasztáson van túl, ${ }^{1}$ melyeket a nemzetközi megfigyelők és szervezetek egyaránt szabadnak és szabályszerünek minősítettek (Ufen, 2018: 307.; Fionna-Tomsa, 2017: 5.), bár egyes szerzők továbbra is rendkívül kritikusak az indonéz demokráciával kapcsolatban: „stagnálónak”, „alacsony minőségünek” (Mietzner, 2012: 209-229.) vagy egyenesen "oligarchikusnak" (Robison-Hadiz, 2004; Fukuoka, 2013) minősítve azt. A magam részéről inkább azon a véleményen vagyok, hogy minden hiányosságával és diszfunkcionalitásával együtt a jelenlegi indonéz politikai 
rendszer mindenképpen kimeríti a demokrácia minimalista, procedurális kritériumait, ${ }^{2}$ sőt azt sem tartom túlzásnak kijelenteni, hogy Indonézia immár túljutott a demokratikus átmenet fázisán és a kétezres évek derekától, legkésőbb a 2004-es választásoktól konszolidált demokráciának nyilvánítható (Barton, 2010: 476.).

Tanulmányunkban a demokrácia és az iszlám kölcsönhatását kívánom vizsgálni az indonéz kontextusban. Nevezetesen: hogy az iszlám mint szociokulturális és politikai faktor milyen szerepet játszott a sikeres demokratikus konszolidációban. Az „iszlám faktor” hatását az indonéz politikai rendszerre meglátásom szerint legalább három elkülönülő elemzési szinten érdemes vizsgálni: 1. a társadalom politikai tagozódásának szintjén: az iszlámhoz, illetve az állam szekuláris jellegéhez füződő viszony képezi mind a mai napig az indonéz társadalom talán legalapvetőbb politikai törésvonalát; 2 . a pártrendszer szintjén: a politikai iszlám platformján álló pártok helye és szerepe az indonéz pártrendszerben; 3. végül, de nem utolsósorban a parlamenti politizálás szintje: a szekuláris és iszlám pártok mennyiben befolyásos alakítói a törvényhozásnak és a végrehajtó hatalom gyakorlásának.

Kutatásunk alapvetően egy kvalitatív, leíró jellegű esettanulmány, amely nem nélkülözi a történeti megközelítést, de implicite módon az összehasonlító szemléletet sem. Mindenekelőtt azonban a politikatudomány és a tranzitológia (a demokratikus átmenet folyamatainak kutatása) fogalomkészletére és módszertanára épít. Így a posztszuhartói korszak pártrendszerének elemzésekor nagyban támaszkodtunk Sartori immár klasszikusnak számító pártrendszer-tipológiájának elemzési kategóriáira, a lijphardti „többségi” és „konszenzusos" demokráciamodell kínálta elméleti keretekre, valamint a parlamentáris és prezidenciális kormányforma előnyeiről és lehetséges hátulütőiről folytatott úgynevezett neoinstitucionalista vita bizonyos következtetéseire.

\section{AZ INDONÉZ SZIGETVILÁG ISZLAMIZÁCIÓJA ÉS A DÉLKELET-ÁZSIAI ISZLÁM SZOCIOKULTURÁLIS JELLEMZŐI}

A délkelet ázsiai iszlámmal kapcsolatban rendszerint annak három meghatározó vonását szokták kiemelni: békés elterjedését, pluralizmusát és toleráns jellegét (Buehler, 2009: 53-54.; Wanadi, 2010: 105.).

Az iszlám békés, kereskedelem általi terjedésének köszönhetően a Malájfélszigeten rendszerint nagyfokú toleranciát tanusított a korábbi hindu-buddhista, illetve animista tradíciókkal szemben. Jáva szigetén például olyan mértéket ért el ez a fajta szinkretizmus, hogy az itt gyakorolt vallás tulajdonképpen csak a felszínen volt iszlám, az indiai, illetve közel-keleti muszlimok, de még saját követői is javanizmus névvel illették, mint egyfajta különálló, heterodox vallási irányzatot. A jávai rádzsák udvarában az iszlám vallásjogot a sariát is 
meglehetősen liberálisan alkalmazták, és a lakosság mindennapi életvitelét sokkal inkább a hagyományos törzsi szokásjog, az úgynevezett adat szabta meg (Hefner, 2000: 32-33.).

A kereskedők mellett az iszlám értékek közvetítésében az utazó vallásjogtudósok és a zarándokok jártak élen. Az ő szerepük különösen azután értékelődött fel a délkelet-ázsiai, valamint az indiai és közel-keleti muszlimok közötti kapcsolattartásban, miután a XVI. századtól kezdve a portugál, majd holland gyarmatosítók teljesen szétzilálták az addig hagyományosan muszlimok által múködtetett kereskedelmi hálózatokat a térségben (Meuelman, 2002: 15.). A mekkai zarándoklatról hazatérő maláj háddzsik a XIX. század második felétől kezdve aztán fokozatosan kezdeményezőivé váltak egy mozgalomnak, amely a délkelet-ázsiai iszlám megreformálását, szinkretista hatásoktól történő megtisztítását és egyfajta pániszlám ideálhoz való közelítését tűzte zászlajára. A modern Indonéziában társadalmi és politikai szinten egyaránt mind a mai napig kitapintható ennek a két vallási szubkultúrának, tehát a tradicionalista-szinkretista iszlám, illetve a reformista-pániszlám irányzatnak a szembenállása.

A két irányzatot azóta már számos megnevezéssel illették, indonézül leggyakrabban abangannak, illetve santrinak nevezik. ${ }^{3}$ A nyugati szakirodalomban általában mint tradicionalista, illetve modernista irányzatként utalnak rájuk (Eliraz, 2004: 21.), azonban különösen ez utóbbi elnevezés bizonyos értelemben félrevezető lehet. A tradicionalisták mindig inkább a délkelet-ázsiai, illetve jávai iszlám megkülönböztető sajátosságait, egyedi voltát hangsúlyozták és igen toleránsan viszonyultak a lokális animista tradíciókhoz. Ezzel szemben a modernisták a délkelet-ázsiai iszlámnak a XIX. századi (mindenekelőtt alAfghánihoz és Muhammad Abduhoz köthető) pániszlám mozgalomba való betagozódását tartották kívánatosnak. Ennek jegyében általában az iszlám fundamentalista ${ }^{4}$ értelmezése mellett szálltak és szállnak síkra. Andreas Ufen annyiban pontosítja a fenti fogalmi distinkciót, hogy az abangan-santri fogalmi dichotómia egyszerúen a szinkretista/heterodox és az ortodox muszlim irányzatok közötti megkülönbözetésre utal és igazából a santrikon belül lehet elkülöníteni a tradicionalista és modernista irányzatot (Ufen, 2008a: 11.). A jávai tradicionalisták jellemzően az ún. Naskabandi szúfi miszticizmus követői, a modernisták viszont elvetik a miszticizmust és az ortodox iszlám puritán értelmezését és gyakorlatát követik (Woodward, 2008: 46.).

A tradicionalista-modernista törésvonal regionális, földrajzi dimenzióban is megnyilvánult. A jávai tradicionális arisztokrácia, valamint a tőlük függő paraszti népesség jellemzően a szinkretista, de mindenképpen tradicionalista irányzatokat követte, míg a modernista-puritán iszlám elsősorban a nagyvárosokban hódított teret, valamint a jávai dominancia alól emancipálódni kívánó régiókban, mindenekelőtt Szumátrán, Sulawesin és a nyugat-jávai szundai 
etnikum körében. ${ }^{5}$ Ezzel is magyarázható, hogy a későbbiekben az indonéz nemzetállamban a jávai centrummal szemben fellépő regionális szeparatizmusok (pl. a szumátrai Acehben) gyakran a politikai iszlamizmus köntösét öltötték magukra (Barton, 2010: 479.).

Megállapíthatjuk, hogy már a gyarmati időszakban, tehát a XX. század '20as, '30-as éveiben megjelentek azok a politikai törésvonalak a nemzeti függetlenségi mozgalmon belül, amelyek bizonyos értelemben mind a mai napig megosztják az indonéz társadalmat. Ezek közül mindenekelőtt kiemelhetjük a szekuláris-iszlamista törésvonalat, amely már a kezdetektől kitapintható volt, ugyanakkor az iszlamista tábor is megosztott volt a tradicionalista-modernista szubkultúrák mentén, amely Andreas Ufen meglátása szerint egyfajta városvidék ellentétet is tükrözött (Ufen, 2008a: 9.).

A szekuláris-vallásos, a tradicionalista-modernista, valamint a város-vidék és szociális törésvonalak mentén négy markáns, egy-egy párt körül kikristályosodó politikai szubkultúra különült el tehát egymástól:

1. a szekuláris-nacionalista Nemzeti Párt (PNI) mögött javarészt a jávai abangan arisztokrácia sorakozott fel, a gyarmati tisztviselői középosztállyal és vallási kisebbségekkel (keresztények, hinduk) karöltve,

2. az ugyancsak erőteljesen nacionalista, jávai bázisú Kommunista Párt (PKI), akiket leginkább az abangan hátterü, nincstelen városi és szegényparaszti tömegek támogattak,

3. a Nahdlatul Ulama (NU) a vidéki elitcsoportok, és birtokos parasztok tradicionalista muszlim pártja,

4. végül a modernista muszlimok, javarészt a Muhammadiyah nevú mozgalom követői, akik a japán megszállás éveiben szerveződtek politikai párttá Majelis Sujra Muslimin Indonesia (Indonéziai Muszlim Felszabadítási Tanács - továbbiakban Masyumi) néven. Ennek a sok tekintetben az egyiptomi Muszlim Testvériség ideológiáját és szervezeti múködését követô pártnak a szavazóbázisa javarészt a nagyvárosi középosztály soraiból, illetve Jáván kivülről (elsősorban Szumátra, Sulawesi) rekrutálódott (Azra, 2002: 33.).

A négy politikai szubkultúrából kettő (a Nemzeti Párt és a kommunisták) hangsúlyozottan szekuláris-nacionalisták voltak, őket leginkább a szociális különbségek választották el egymástól, az iszlamista tábort ugyanakkor a tradicionalista-modernista törésvonal osztotta meg. A négy párt közül a Masyumi határozottan nagyvárosi, míg a Nadhlatul Ulema egyértelmúen vidéki kötődésű volt. A Nemzeti Párt és a kommunisták szavazóbázisa viszont nem polarizálódott a város-vidék törésvonal mentén (Ufen, 2008a: 10.). Ezeket a szakirodalomban, Clifford Geertz kultúrantropológus kifejezésével gyakorta alirannak (áramlatnak) is nevezett politikai szubkultúrák ${ }^{6}$ - melyek szembeötlő párhuzamot mutattak a gyarmattartó Hollandia "oszloposodott társadalmával” - 
figyelemre méltóan tartós struktúráknak bizonyultak és a függetlenség elnyerése utáni években is döntően meghatározták az indonéz pártpolitikát.

\section{A FÜGGETLENSÉG ELNYERÉSE; A PÁRTRENDSZER ÉS A SZEKULÁRIS- ISZLAMISTA KONFRONTÁCIÓ SZUKARNO ELNÖKSÉGE ÉS AZ „IRÁNYÍTOTT DEMOKRÁCIA" IDŐSZAKÁBAN}

A függetlenség első éveiben - sőt már azt megelőzően is - a politikai diskurzus főtengelyébe az indonéz állam szekuláris, illetőleg deklaráltan iszlám jellegével kapcsolatos viták kerültek. Szukarno elnök - a függetlenségi mozgalom szekuláris-nacionalista szárnyának vezetője - a híres és később az indonéz állam alapvetésévé váló öt elv, a Pancasila beterjesztésével kívánta áthidalni az ellentéteket. ${ }^{7}$ Ezek közül az első alapelvet, a Szukarno által beterjesztett formában „Hit Istenben”-t, a muszlim szervezetek túl általánosnak találták és elutasították, illetve a későbbiekben kiegészítését javasolták "Hit Istenben, az Iszlám követóinek azzal a kötelességével, hogy az Iszlám jognak érvényt szerezzenek." (Bertrand, 2003: 32.). Végül annyi engedményt tettek csak a muszlim szervezetek felé, hogy az első alapelv végleges megfogalmazása nem „Hit Istenben” hanem „Hit egy Istenben” lett (Barton, 2010: 480.). Az alkotmány alapján tehát az iszlám pártok követelésével szemben nem lett államvallás az iszlám, az állam pedig nem vált teokráciává, noha nyugati értelemben teljes mértékig szekulárisnak sem nevezhető, hiszen állampolgáraitól mind a mai napig megköveteli a hat elismert vallásfelekezet ${ }^{8}$ egyikéhez való tartozást. Szigorú törvények büntetik az istenkáromlást is (Azra, 2006: 37.).

Az első szabad választásokra végül is 1955-ben kerítettek sort, az iszlám pártok pedig, amelyeket a Pancasilában megfogalmazott kompromisszum nem elégített ki, nagy reményeket füztek hozzá: úgy vélték ha az Alkotmányozó Gyưlésben ők szerzik majd meg az abszolút többséget, korrigálhatják Szukarno korábbi „iszlámellenes” döntéseit.

Az 1955-ös választások eredménye híven tükrözte az aliran-szubkultúrák politikaformáló erejét, a pártrendszer elsősorban a szekuláris-vallásos és tradicionalista-modernista törésvonalak mentén strukturálódott. A nagy tömegpártok közül legjobban Szukarno elnök pártja, a Nacionalista Párt szerepelt, a szavazatok 22\%-át begyüjtve. Szintén meglepően jól szerepeltek a kommunisták, akik 16\%-ot szereztek. A modernista muszlim Masyumi 20\%-os eredménye, a várakozásokhoz képest csalódást keltett. Egyedül ennek a pártnak a programjában szerepelt az iszlám állam megteremtése. A mérsékeltebb, tradicionalista muszlim Nahdlatul Ulama 18\%-ot ért el. A muszlim pártokra öszszességében tehát csaknem pontosan ugyanannyian szavaztak, mint a nacionalista-kommunista blokkra (Hefner, 2000: 43.). 
Miként azonban Marcus Mietzner is megállapítja a pártrendszer összességében igen fragmentált maradt, hiszen bár a fent említett négy politikai erő gyüjtötte be a szavazatok több mint 70\%-át, összesen 35 (!) politikai párt jutott be az Alkotmányozó Gyúlésbe. Az adott kontextusban még inkább súlyosbította a helyzetet, hogy sem a "szekuláris”, sem az „iszlamista” politikai blokk nem rendelkezett az alkotmányozáshoz szükséges kétharmados többséggel. Az Alkotmányozó Gyúlésben lényegében feloldhatatlan politikai patthelyzet alakult ki, a többszöri nekifutásra is eredménytelen alkotmányozási vita pedig egyre inkább radikalizálta a szemben álló feleket. Az 1955-ös választások nyomán formálódott indonéz pártrendszert Sartori terminológiájával tehát egy tipikus polarizált sokpártrendszernek minősíthetjük, melyben, miként az erősen töredezett pártrendszerek kapcsán gyakran tanúi lehetünk, egy centrifugális dinamikájú pártverseny bontakozott ki, amely a pártpolitika végletes radikalizálódásához és végül a demokratikus politikai rend összeomlásához vezetett (Mietzner, 2008: 433-438.).

Szukarno elnök végül is megelégelve a többéves huzavonát, 1959 júliusában a hadsereg támogatásával feloszlatta az Alkotmányozó Gyúlést és rendeletileg vezette be az új alkotmányt - pontosabban deklarálta az első 1945-ös indonéz alkotmányhoz való visszatérést (Barton, 2010: 481.). 1960-ban a Masyumi-pártot betiltották, annak vezető politikusai közül többet is bebörtönöztek, ugyanakkor a párthoz kötődő ifjúsági szervezetek és vidéki milíciák továbbra is múködhettek. Szukarno azonban megfizette a politikai iszlám háttérbe szorításának árát: az addig kényesen a hadsereg és a kommunisták között egyensúlyozó elnök egyre inkább az utóbbiak befolyása alá került (RabasaHaseman, 2002: 35.). A kommunisták által szorgalmazott gazdaságpolitikának köszönhetően, 1965-re az indonéz gazdaság az összeomlás szélére került, miközben különböző természeti katasztrófáknak köszönhetően Jáván már így is milliók éheztek.

Az eszkalálódó gazdasági és politikai válság végül kiváltotta a hadsereg beavatkozását. A hadsereg Stratégiai Tartalék Parancsnokságának vezetője, Szuharto tábornok eleinte kerülni kívánta a nyílt katonai hatalomátvétel látszatát, ezért nem direkt a hadsereget vetette be, hanem a muszlim pártok, így a Nahdlatul Ulama és a betiltott Masyumi milíciáit hívta segítségül. 1965 decemberében a muszlim milicistáknak és számos esetben a spontán népharagnak legalább félmillió kommunista párttag (illetve azok családtagjai) esett áldozatul Indonézia szerte. Ezzel gyakorlatilag fizikai értelemben is megsemmisítették egész Ázsia legrégebbi és egyik legnagyobb taglétszámú kommunista pártját, habár a kommunista párt formális betiltására csak 1967-ben került sor. Ugyanebben az évben mondatta le a törvényhozás Szukarno elnököt és választotta Szuharto tábornokot államfővé. Szukarnót, bár soha nem helyezték jogi eljárás alá, lényegében egészen 1970-ben bekövetkezett haláláig háziőrizetben tartották (Hefner, 2000: 70.). 


\section{HATALOMGYAKORLÁS ÉS PÁRTRENDSZER \\ A SZUHARTÓI „ÚJ REND” IDŐSZAKÁBAN}

Az iszlám pártok komoly várakozásokkal tekintettek a Szuharto féle „Új Rend” beköszönte elé, ám végsősoron csalódniuk kellett. A hadsereg vezetői nem kívántak különösebben széles teret nyitni az iszlám pártok számára a politikai életben. Az „Új Rend” ideológiai alapját elviekben az 1945-ös Pancasila szolgáltatta, ezt valamint a rezsim antikommunizmusát és a hivatalos szintre emelt nacionalizmust egyetlen politikai szereplő sem kérdőjelezhette meg nyilvánosan. 1985-ben az összes társadalmi és politikai szervezet - így a muszlim szervezetek számára is - kötelezővé tették a Pancasila mint "egyedüli alapelv" (asas tunggal) elismerését (Azra, 2002: 34.).

Ami a politikai pluralizmust és a pártok közötti szabad versengést illeti, azt Szuharto uralmának idején még Szukarno „irányított demokráciájának” időszakához képest is erőteljesebben korlátozták. Szuharto újonnan szervezett mozgalma a Golkar - a Golongan Karya azaz "funkcionális csoportok” rövidítéséből - a rezsim de facto állampártjaként funkcionált (Sulistyo, 2002: 77.). Mint az elnevezés is mutatja, a Golkar a régi „aliran alapú" hagyományos pártokkal összevetve, kevéssé rendelkezett karakteres ideológiai profillal, sőt szigorúan jogi értelemben véve nem is egy párt volt, hanem különféle funkcionális és érdekcsoportok ernyőszervezete. Szerepe egyrészt a rezsim pragmatikus-technokrata arculatának megjelenítése volt, hogy az állami bürokrácia és hadsereg tagjainak lojalitását és ezen keresztül a kellő számú támogató szavazatot választásról választásra biztosítsa. Ami azt illeti, „szavazatszerző gépezetként" a Golkar valóban nem teljesített rosszul, hiszen a '71-et követő hat parlamenti választás (1974, 1977, 1982, 1987, 1992 és 1997) során minden alkalommal a szavazatok több mint 60\%-át gyújitötte be a kormánypárt (Sulistyo, 2002: 77.).

Ami a parlamenti ellenzéket illeti, a még létező jelentősebb ellenzéki pártokat arra kényszerítették hogy fuzionáljanak két alakulatba. Szukarno bukása után a népszerúségéből jelentős mértékben veszítő Nemzeti Pártot a katolikus és protestáns közösségek pártjaival egyesítették, így hozva létre az Indonéz Demokrata Pártot (Partai Demokrasi Indonesia - PDI), míg a muszlim pártokat, így a Nahdlatul Ulemát és a Masyumi utódszervezetét, a Parmusit (Partai Muslimin Indonesia - Indonéziai Muszlimok Pártja) az Egység és Fejlődés Pártban (Partai Persatuan dan Pembangunan - PPP) olvaszották össze. A rendszer Patyomkin-ellenzékének ezzel tulajdonképpen lett egy "szekuláris” és egy „iszlamista” szárnya, habár ez utóbbi „iszlám” jellegét inkább csak valamiféle hallgatólagos közmegegyezés övezte. Természetesen a PPP sem kérdőjelezhette meg a Pancasilát, mint kizárólagos állami ideológiát, programjában, szimbólumaiban, de még a párt nevében sem utalt semmi az Iszlámra, 
vagy a párt bármiféle iszlamista jellegére (Bertrand, 2003: 39.). Ennek ellenére szembeötlő kontinuitás figyelhető meg, amennyiben a korábbi NU és Parmusi, valamint a PPP szavazati arányait tekintjük: a hat egymást követő parlamenti választáson mindig a szavazatok 15-25\%-át szerezték meg, legjobb eredményüket az 1977-es választáson érték el, ekkor a voksok 29\%-a jutott nekik (Sulistyo, 2002: 77.).

Összefoglalóan tehát az „Új Rend” pártrendszerét Sartori terminológiájával egy tipikus hegemón pártrendszerként jellemezhetjük, amely formailag ugyan nem volt egypártrendszer, de a politikai pártok közötti szabad versengést intézményesen korlátozták, csaknem három évtizedre bebiztosítva ezzel a gyakorlatilag állampártként funkcionáló Golkar hatalmi monopóliumát. Az ellenzéki Demokrata Pártnak és a PPP-nek ebben a szisztémában jobbára csak statisztaszerep jutott, a parlamenti politikát és kormányzati döntéshozatalt nem tudták érdemben befolyásolni. Ennek ellenére a PPP konstans szavazati arányai arra engednek következtetni, hogy társadalmi és szociokulturális szinten tovább éltek a tradicionalista és modernista muszlim politikai szubkultúrák, a jobbára föld alá szorított iszlám politikára pedig továbbra is lett volna komoly társadalmi igény.

Sőt, ami azt illeti, a Szuharto-korszakban a politikai iszlám teljes marginalizálódása ellenére - vagy talán többek között éppen emiatt - társadalmi és szociokulturális szinten egyfajta "modernista iszlám reneszánsz" ment végbe, ami egyébként jól illeszkedett az ekkortájt az egész muszlim világon végigsöprő reiszlamizációs hullámba (Barton, 2010: 485.). Ahogy Robert Hefner is megállapítja immár klasszikus, a "civil iszlám”-ról írt monográfiájában, a kilencvenes évek elejére Indonéziában kiformálódott egy plurális és differenciált muszlim „civil szféra”, a maga kiterjedt szervezeti hálózatával, pártjaival, egyesületeivel és sajtójával (Hefner, 2000). Ezek között a muszlim civil szervezetek között voltak kimondottan politikai jellegúek és olyanok, amelyek hangsúlyosan távol tartották magukat a politikától, voltak olyanok, melyek a liberális és demokratikus értékek fontosságát hirdették és olyanok is, amelyek fundamentalista alapról elutasították azokat. Nem voltak alaptalanok tehát azok a várakozások, hogy a rendszerváltás nyomán egy demokratikus Indonéziában felerősödhet a politikai iszlamizáció folyamata, vagy legalábbis hasonlóan az 1950-es évekhez, az ismét katalizálódó szekuláris-iszlamista konfrontáció válhat a demokratikus politikai közösséget megosztó legfontosabb törésvonallá. Ezeket a várakozásokat és félelmeket azonban meglátásom szerint az 1998 után kibontakozó pártverseny és parlamenti politizálás dinamikája mindezideáig kevéssé igazolta vissza. Tanulmányom következő fejezetében ennek a részletesebb vizsgálatára és magyarázatára teszek kísérletet. 


\section{PÁRTVERSENY ÉS POLITIKAI ISZLÁM A „POSZTSZUHARTÓI” KORSZAKBAN}

1997 augusztusában Indonéziát megrázta modernkori történetének legsúlyosabb pénzügyi, majd gazdasági válsága. Az ennek nyomán kirobbanó zavargások ${ }^{9}$ lerombolták a Szuharto-rezsim maradék tekintélyét is, belföldön és a nemzetközi színtéren egyaránt. Szuharto végül is 1998. május 18-án lemondott, átadva a hatalmat alelnökének és egyben kiszemelt utódának, a mérnök végzettségü és pragmatikus technokrata imidzset ápoló Juszuf Habibie-nek (Sulistyo, 2002: 78).

Habibie átmeneti - egyébként meglehetősen rövid életűnek bizonyult, mindössze másfél éves - elnökségétől számíthatjuk a "reformasi”, a politikai reformok, vagyis az indonéz rendszerváltás időszakát (Tanthowi, 2012: 11.). A javarészt 1998-2005 között elfogadott alkotmánymódosítások valóban alapjaiban formálták át az indonéz politika intézményi kereteit. 1999-ben új választási törvényt fogadtak el és liberalizálták a politikai pártok múködését (Sulistyo, 2002: 79.). Ennek köszönhetően 1955 óta sor kerülhetett az első valóban versengő és többpárti választásokra. A törvény adta lehetőségeket kihasználva több mint 200 új politikai párt jött létre. Miután feloldották a pártok számára a Pancasila mint egyedüli kizárólagos ideológiai alapelv elismerésének kötelezettségét, az új pártok között mintegy negyven iszlamista színezetü politikai erő is alakult (Azra, 2006: 41.).

2004 óta az indonéz állampolgárok nemcsak a parlamenti képviselőket, de az elnököt, illetve a tartományi kormányzókat (az ún. pilkadákat) is közvetlenül választják. Azontúl, hogy ez alkotmányos szinten is az elnöki típusú kormányformára történő maradéktalan áttérést jelentett, ennél általánosabb értelemben is az indonéz politikai rendszer "prezidencializálódásához", mindenekelőtt a választási küzdelem személyközpontú jellegének a felerősödéséhez vezetett (Ufen 2018; Aspinall 2011: 297.). Szintén a perszonalizációs tendenciákat erősíti, hogy bár az indonéz választási rendszer tisztán arányos-pártlistás alapú, 2009 óta az 560 fős parlament képviselőit 77 többmandátumos választókerületben, nyíltlistás rendszerben választják (Ufen, 2018: 3.).

Ami a pártrendszer tagozódását és a pártverseny dinamikáját illeti: első látásra is szembetűnő és nyilvánvalóan az arányos választási rendszer alkalmazásának is betudható a posztszuhartói korszak pártrendszerének nagyfokú fragmentációja. Az 1999 és 2014 között megtartott eddigi négy parlamenti választáson a parlamentbe jutó pártok száma átlagban 14 volt. Ez igen magas érték, még akkor is ha valamelyest csökkenő tendenciát mutat: 1999-ben 21, 2004-ben 16, 2009-ben 9, míg 2014-ben 10 párt jutott be a törvényhozásba (Highashikata-Kawamura, 2015: 8.). Ugyanakkor a pártok úgynevezett effektív és a parlamenti pártok effektív száma ${ }^{10}$ még növekedett is az elmúlt húsz évben: 1999-ben 5,1 és 4,7; 2004-ben 8,6 és 7,1; 2009-ben 6,1 és 6,2; míg 2014- 
ben 8,9 és 8,2 volt a két szóbanforgó érték - ami viszont összességében növekvő töredezettségre utal (Highashikata-Kawamura, 2015: 36.). Ez alapján a pártrendszer effektív számértéke (a parlamenten kívüli pártokkal is kalkulálva) 7,1, a parlamenti pártok effektív száma 6,55-ös értéket mutat az elmúlt húsz év átlagában (Fionna-Tomsa, 2017: 5.). Ezek nemzetközi összehasonlításban is igen magas számok.

Ráadásul az adatok nem pusztán a parlamenti pártok relatíve magas számáról, hanem szavazóik igen nagy mértékű fluktuációjáról is tanúskodnak. A Higashikata-Kawamura szerzőpáros szerint tehát míg a posztszuhartói korszak demokráciája általánosságban stabilnak és konszolidáltnak tekinthető, a rendszerváltás utáni indonéz pártrendszer már korántsem az (HigashikataKawamura, 2017: 2.). Az ingadozó szavazók aránya 2004-ben (az előző választáshoz képest) 23\% volt, 2009-ben 28,7\%, 2014-ben pedig 26,3\%. Ez az érték majdnem háromszorosa a „konszolidált” nyugat-európai demokráciák 1885 és 1985 között számított átlagának - igaz a kilencvenes években demokratizálódott Latin-Amerikával vagy Kelet-Európával összevetve már korántsem tekinthető kiugróan magasnak (Highashikata-Kawamura, 2015: 7.).

Ugyanakkor az újonnan demokratizálódó országok pártpolitikai dinamikáját általában jellemző relatíve erős volatilitás mellett a posztszuhartói pártrendszerben a stabilitás és kontinuitás bizonyos elemei is felfedezhetőek. Mint arra a Fionna-Tomsa szerzőpáros is felhívja a figyelmet 1999 óta hat párt állandó jelleggel jelen van a törvényhozásban, ennek a hat „magpártnak” az együttes parlamenti mandátumaránya 1999-ben 88\%, 2004-ben 72\%, 2009ben 52\% míg 2014-ben 63\%-ot tett ki (Fionna-Tomsa, 2017: 5.). A „magpártok” pedig, ha alaposabban megvizsgáljuk őket figyelmre méltó kontinuitást mutatnak a szuhartói „Új rend” időszakának pártjaival, sőt még a Szuhartókorszakot megelőző időszak meghatározó szubkultúráival, az „aliranokkal” is felfedezhetőek bizonyos kapcsolódások.

Az 1950-es évek négy nagy politikai szubkultúrájából három úgy tûnik a posztszuhartói korszakban is tovább él: a Nemzeti Párt hangsúlyozottan szekuláris-nacionalista irányvonalát, a Megawati Sukarnoputri (elnök 2001 és 2004 között) által vezetett Demokrata Párt (hivatalosan Indonéz Demokrata Párt - Küzdelem; Partai Demokrasi Indonesia - Perjuangan, PDI-P) vitte tovább, amely a Szuharto-korszak szalonellenzékéből a kilencvenes évekre valódi ellenzéki erővé érett és bizonyos értelemben a szukarnói „örökség” hordozója maradt. Az Abdurrahman Wahid professzor (elnök 1999 és 2001 között) neve által fémjelzett Nemzeti Ébredés Pártja (Partai Kebangkitan Bangsa - PKB) szoros személyi, szervezeti és ideológiai folytonosságot mutatott a tradicionalista muszlimok szervezetével a Nahdlatul Ulamával. A modernista muszlim szubkultúra ehhez képest pártpolitikai szinten lényegesen fragmentáltabb formát öltött: tovább múködött a Masyumi utódjának tekinthető, és a Szuharto-korszak "hivatalos" iszlamista ellenzékét képező PPP,11 de szintén a modernista musz- 
lim tömegszervezetekhez, nevezetesen a Muhammadiyahhoz kötődött a Nemzeti Üdvpárt (Partai Amanat Nasional - PAN), valamint az előzőeknél radikálisabbnak tekinthető, az iszlamista kampuszmozgalomból kinövő Igazság (később Igazság és Jólét) Párt (Partai Keadilan Sejahtera - PKS). A kommunisták által képviselt radikális baloldali tradíciónak ugyanakkor a posztszuhartói politikai palettán nem maradt örököse, sokak meglepetésére a demokratikus verseny körülményei között is tartós tényező tudott maradni viszont a Golkar a bürokraták és állami funkconáriusok technokrata arculatú formációja (Ufen 2008b: 17.).

A hat „magpárt” közül kettő kimondottan szekuláris (a PDI és a Golkar) a másik négy viszont deklaráltan vagy - legalábbis szavazóbázisának kötődését tekintve - burkoltan, mérsékeltebb vagy radikálisabb iszlamista platformon állt. ${ }^{12}$ Ugyanakkor ha a szavazati arányokat tekintjük az összkép már kevésbé hízelgő az iszlamista pártokra nézve: 1999-ben a négy iszlamista magpárt öszszesen a szavazatok 33\%-át kapta, nagyságrendileg tehát annyit, mint a Szukarnoputri vezette PDI egymagában. A szavazatok és a parlamenti mandátumok többségén, csaknem hatvan százalékán két szekuláris párt a PDI és a Golkar osztozott. Higashikata és Kawamura számításai szerint 1999 óta az iszlamista pártokra adott szavazatok aránya konstans jelleggel a 30-50\% körüli sávban mozog (Higashikata- Kawamura, 2015: 11.). Ugyanakkor ez a kijelentés is csak abban az esetben állja meg a helyét, ha elfogadjuk a kiinduló premisszát, miszerint például a tradicionalista PKB vagy éppen a modernista PAN „iszlamista pártok”, noha ezek a politikai alakulatok a posztszuhartói korszakban felhagytak a saría alkotmányba emelésére vonatkozó követelésükkel és továbbra is a Pancasila elveit tartják magukra nézve meghatározónak (Eliraz, 2002: 69.; Hosen, 2005: 426.). 1999 óta még a PKS iszlamista retorikája is jelentősen mérséklődött és programjuk is némileg felhígult - sokak szerint pusztán taktikai okokból, de felhagytak az iszlám állam követelésével (Woodward, 2008: 54.). De ha továbbra is őket tekintjük a szorosabb értelemben vett „iszlamista” pártnak, akkor is kijelenthetjük, hogy az iszlám saría alapján álló állam programja az indonéz szavazók legfeljebb 10\%-a számára vonzó.

Ami a fent említett pártok választói támogatottságának területi megoszlását illeti, a kontinuitás ezen a téren is megfigyelhető az ötvenes évek első demokráciájának mintázatával. A PDI-P akárcsak elődje a PNI elsősorban a jávai abangan szavazói csoportok és vallási kisebbségek, mindenekelőtt a keresztény szavazók és a balinéz hinduk körében erős. A PKB fellegvárát Közép és Kelet-Jáván a tradicionalista és jellemzően inkább vidéki muszlim közösségek képezik, csakúgy mint a „preszuhartói” korszakban a Nahdlatul Ulamáét (Ufen, 2008a: 15.). A modernista muszlim szubkultúra pártjai hagyományosan inkább nagyvárosokban és Jáván kívül erősek. A modernista, ám viszonylag mérsékelten iszlamista PPP legerősebb bástyája Észak-Szumátra Aceh tarto- 
mánya. Az eredendően a Muhammadiyához kötődő PAN szintén Szumátrán, a fővárosban Jakartában és a pártalapító Amien Rais - a Muhammadiya szervezet korábbi elnöke és a Gadjah Mada Egyetem professzora - szúkebb pátriájában, a jávai Yogyakarta körzetében erős, bár a párt jelöltje nyerte 2018-ban Dél-Sulawesin is a kormányzóválasztást. A többi muszlim pártnál radikálisabbnak tartott modernista PKS kiugróan erős Jakartában a fơvárosban, ${ }^{13}$ ahol népszerüségük csúcsán 2004-ben és 2009-ben a szavazatok több mint 20\%-át megszerezték (Woodward, 2008: 54.; Fionna-Tomsa, 2017: 36.). A Golkar támogatását mindezekkel a pártokkal szemben nagyobb arányban meríti a perifériálisabb régiókból így Szumátáráról, Kalimantanról és a keleti (értsd Balitól keletre fekvő) „külső” szigetekről, mint Sulawesi, Maluku vagy éppen Pápua (Ufen, 2008a: 15.).

Ehelyütt talán érdemes felhívni a figyelmet arra is, hogy bár az országos nagy pártok szavazóbázisa kétségtelenül mutat bizonyos területi mintázatot, ahogy az '50-es évek „első demokráciájában” úgy a posztszuhartói korszak indonéz belpolitikában sem váltak meghatározóvá a regionális törésvonalak és az ország nem vált az etnonacionalista politikai mozgósítás terepévé, dacára annak, hogy a Szuharto-rezsim bukását követően fellángoló szeparatista és etnikai konfliktusok nyomán, sokan ennek éppen az ellenkezőjére számítottak. Ez azontúl, hogy az indonéz nemzettudat viszonylagos erejéről, és az etnikai identitások kevéssé átpolitizált minőségéről is tanúskodik, a pártok közötti versengés intézményi szabályozásának is köszönhető. A közigazgatásban a tartományi szint adminisztratív meggyengítése a szubprovinciális körzetek javára, a tisztán arányos választási rendszer, valamint az a szabály, hogy a nemzeti törvényhozásba bejutni kivánó pártokban, legalább a tartományok kétharmadában (és azon belül a körzetek kétharmadában) jelöltet kell állítaniuk, ${ }^{14}$ mind-mind a regionális szinten vagy tartományi alapon szerveződő pártok létrejötte ellen hatott és az indonéz pártrendszer ideológiai alapú tagozódását segítette elő (Aspinall, 2011: 296.; Ufen, 2008a: 16.).

Az indonéz pártrendszer ideológiai tagozódását pedig jelentős részben még mindig az 1950-es évek első demokráciájának időszakából átörökölt „aliran” szubkultúrák szabják meg. Ahogy azt számos elemző megállapította az egyébként relatíve nagymértékú pártok közötti szavazatingadozás is jellemzően ezen szubkulturális blokkokon belül ment végbe, tehát egyes iszlamista pártok például a PPP - szavazatveszteségéből általában nem a szekuláris politikai erők, hanem más iszlamista pártok, például a PKS profitáltak. Az „iszlamista” és a „szekuláris” szavazói blokkok között tehát úgy tűnik továbbra is csekély mértékú az átjárás (Hagashikata-Kawwamura, 2015: 11.; Mietzner, 2008: 440.). Az ideológiai alapú blokkosodás és a fragmentált politikai paletta alapján érvelhetnénk amellett is, hogy a posztszuhartói korszakban, hasonlóan az 1950es évek „első demokráciájához", egy centrifugális dinamikájú polarizált sokpártrendszer formálódott ki. Ráadásul a politikatudományban már-már 
közhelyszerüen hivatkozott álláspont, hogy az arányos-pártlistás választási rendszer, az ennek folytán fragmentálódott sokpártrendszer és tisztán prezidenciális jellegű kormányforma párosítása nem igazán szerencsés, mivel világos támogató többség hiányában a törvényhozás és végrehajtó hatalmi ág közötti konfliktusok állandósulhatnak, destabilizálva az egész demokratikus politikai rendet (Mainwaring-Shugart, 1993; Linz, 1994; Mietzner, 2016). Ezekre a várakozásokra azonban a posztszuhartói pártrendszer dinamikája és a kormányzati rendszer viszonylagos stabilitása egyaránt rácáfolni látszik.

Miként Marcus Mietzner is megállapítja, a centrifugális spirál, a szembenálló szavazói blokkok és pártjaik radikalizálódása helyett a posztszuhartói korszakban alapvetően egy centripetális, mérséklő dinamikájú pártverseny bontakozott ki (Mietzner, 2008). Ennek magyarázata úgy gondolom számos faktorra visszavezethető. Először is: bár az indonéz társadalomban a politikai szubkultúrák szintjén továbbra is kitapintható a szekuláris-iszlamista törésvonal, a pártrendszer szintjén a politikai erők - szemben az ötvenes évekkel - mégsem két mereven szembenálló blokkban rendeződnek. Egyrészt, ahogy a fentiekben már említettük az „iszlamista” blokk pártjai esetében erősen kérdéses mennyire vehetőek ezek a politikai erők egy kalap alá: a PKB, a PPP és a PAN kimondottan mérsékelt pártok amelyek hivatalosan mindig is elfogadták a Pancasila ideológiát, de a náluk radikálisabbnak tartott, némileg elitellenes-populista PKS is mindig betartotta a parlamenti demokrácia játékszabályait. A meghatározó szekuláris politikai erők, így a PDI-P és a Golkar is jellemzően pragmatikus, centrista politikai irányvonalat követnek. Az ötvenes években a kommunisták által megjelenített szekuláris-ideologikus radikalizmus gyakorlatilag teljesen hiányzik a jelenlegi indonéz politikai palettáról. Ennek köszönhetően radikalizáció helyett a politikai centrum „tömegvonzása" érvényesül a szétaprózott sokpárti környezetben is (Mietzner, 2008: 444447.). Napjainkban az indonéz pártok ideológiai profilja általánosságban véve is sokkal inkább konfúzus, mint az '50-es években, és a hagyományos politikai szubkultúrákhoz kötődő „magpártokat” is sokkal inkább egy-egy karizmatikus személyiség, mintsem valamiféle markáns ideológiai karakter dominálja. ${ }^{15}$

Erre a centripetális dinamikára és a perszonalizációs folyamatokra indirekt módon bizonyos intézményi reformok is ráérősítettek. 2004-től kezdve a közvetlen elnökválasztások, majd 2005-től a közvetlen tartományi kormányzóválasztások, valamint 2009-től a parlamenti választásokon a nyíltlistás szisztéma bevezetése összességében gyengítette a politikai pártok szerepét és erősítette a személyközpontú tendenciákat (Fionna-Tomsa, 2017: 15-18.). Olyannyira, hogy 2004-től az indonéz politikai palettán a hagyományos "aliran” kötődésú „magpártok” mellett, megjelentek merőben új típusú „egyszemélyi” politikai mozgalmak. Ilyen volt a népszerú nyugalmazott tábornok Szuszilo Bambang Yudhoyono (elnök: 2004-2014) „Demokrata Pártja” (Partai Demokrat-PD), aki 
miután Sukarnoputrival szemben alulmaradt a PDI-ben, saját mozgalmat indított magának, amely gyakorlatilag a semmiből betörve a politikai fóáramba, 2004-ben egy csapásra a harmadik legtöbb mandátumot szerző párt lett. Ehhez hasonlóan egy korábbi tábornok Prabowo Subianto személyi ambícióit szolgálja a Nagy Indonéziáért Mozgalom (Gerakan Indonesia Raya - Gerakan), amelyet Szuharto egykori veje azután alapított, miután 2004-ben Aburizal Bakrievel szemben alulmaradt a Golkar párt vezetéséért folytatott küzdelemben. De Wiranto generális 2006-ban alapított Népi Öntudat Pártjáról (Partai Hati Nurani Rakyat - Hanura), vagy a Surya Paloh médiacézár által életre hívott Nemzeti Demokrata Pártról (Partai Nasional Demokrat - NasDem) ugyanezt mondhatjuk el (Ufen, 2018: 12.).

A posztszuhartói korszak pártpolitikája és parlamenti politizálásnak mozgatója sokkal inkább a személyi patronázsküzdelmek és klientelizmus mintsem az ideológiai konfrontáció (Aspinall-Sukmajati, 2016). A kormányzati patronázspozíciókból való részesedés az elmúlt két évtizedben döntő motivációnak bizonyult az iszlamista pártok számára is, hogy igyekezzenek részt vállalni a kormányzásban, ahelyett, hogy ellenzékbe vonulnának (Mietzner, 2008: 445.; Ufen, 2018: 10.). Másfelől a széttagolt sokpárti indonéz parlamenti paletta kontextusában az államfők is csak minél szélesebb "szivárvány koalíciók” kiépítésével tudták hatékonyan gyakorolni a végrehajtó hatalmat. Joko Widodo elnök kihasználva a parlamenti pártok belső hatalmi harcait számos esetben a kormányát támogató frakciókat juttatta hatalomra (Ufen, 2018). Ennek köszönhetően bár „Jokowi” elnök 2014-ben a parlamenti választásokon csupán a mandátumok 19\%-át megszerző PDI-P jelöltjeként jutott hatalomra, de ma lényegében egy hatpárti - a PDI-P-t, a Golkart, a Hanurát, a Nasdemet, a PKBt, és a PPP-t magában foglaló - koalíció élén kormányoz. A négy parlamenti iszlamista pártból, tehát kettő támogatja a regnáló elnököt. A tulajdonképpeni politikai ellenzéket, így a jelenlegi ciklusban a Jokowi elnök személyes ellenlábasának tekinthető Prabowo tábornok Gerindra pártja és a politikai identitását az iszlamizmus mellett nem kis részben a megalkuvás mentes elit és korrupcióellenességre építő PKS alkotja. ${ }^{16}$ A PAN pozíciója az elmúlt parlamenti ciklusban némileg képlékenynek bizonyult: ők is évekig támogatták Jokowi elnököt, de a 2019-es elnökválasztásokon úgy tûnik mégis inkább kihívója, Prabowo Subianto mögött sorakoznak fel. ${ }^{17}$ Cserében az elnöki hatalom támogatásáért, néha a kormányzat is felvállalja az iszlamista pártok politikai agendáját: mint történt az eredetileg a PAN által szorgalmazott pornográfia elleni törvény megszavazásakor 2006-ban (Ufen, 2018: 24.).

A 2019-es elnökválasztásra előretekintve a meglehetősen fluktuens indonéz pártrendszerben két nagyobb szembenálló tábor látszik kiformálódni. Jokowi elnököt a PDI-P, Golkar, Hanura, NasDem, PKB és PPP pártok meglehetősen heterogén koalíciója támogatja, míg fő kihívóját Prabowo tábornokot egy nem kevésbé tarka, Gerindra, PD, PAN, PKS szövetség jelöli. Ha a 
PPP-t mint tradicionalista muszlim pártot tekintjük, Jokowi koalíciójának öszszetétele némileg emlékeztethet minket Szukarno NASAKOM kormányára (azzal a nem elhanyagolható különbséggel persze, hogy ebben a szövetségben kommunisták nem vesznek részt). Az ellenzék viszont távolról sem csak a modernista muszlim pártokat, hanem a szekuláris politikai erőket is magában foglalja. Az ötvenes évek szekuláris - iszalmista politikai törésvonalának újraéledéséről tehát csak bajosan lehetne beszélni. Különösen, hogy jokowi egy 75 éves muszlim hittudóst, Ma'ruf Amint választotta alelnökjelöltjéül. ${ }^{18}$

Az is gyakran megfigyelhető, hogy a parlamenti politizálás során a törvények sorsa pártközi háttéralkuk eredményeképpen a nyilvánosság elől zárt bizottsági üléseken dől el és a parlamenti pártok a döntést végül is konszenzussal és nem szavazással hozzák (Ufen, 2008b: 32.). A parlamenti törvényhozási folyamat emiatt sokak számára korruptnak és kevéssé transzparensnek tûnhet, de az indonéz modell múködése szemlélhető pozitív értelemben egyfajta sokpárti konszenzusorientált demokráciaként - akárcsak az egykori gyarmattartó Hollandiáé -, ahol a politikai döntéshozatal nem egyoldalú módon, egy esetleg csak relatív többségi felhatalmazást szerző politikai erő kezében van, hanem igyekeznek minél több politikai szubkultúrát bevonni a törvényhozás folyamatába és a végrehajtó hatalom gyakorlásába is. Bár az indonéz alkotmányos berendezkedés tüzetesebb vizsgálata nem képezte tanulmányunk tárgyát, de ehelyütt jegyeznénk meg, hogy meglátásunk szerint a párhuzamosan fennálló politikai szubkultúrákra fragmentálódott társadalom és sok pártrendszer mellett, az indonéz demokrácia konszenzusos vonásait erősítik olyan alkotmányos/intézményi tényezők is, mint az arányos választási rendszer vagy a törvényhozás és elnök relációjában fennálló, prezidenciális rendszerekre jellemző nagyfokú hatalommegosztás, valamint a közigazgatás elmúlt években lezajlott erőteljes decentralizációja is.

\section{KONKLÚZIÓ}

Tanulmányunkban a politikai demokrácia adaptálásának lehetőségeit vizsgáltam a délkelet-ázsiai iszlám kontextusában. Az indonéz demokrácia történetében végig kitapintható egy egymással hol szembenálló, hol együttmúködő szekuláris, illetve iszlám politikai szubkultúra. Ez utóbbi tovább tagolódik a tradicionalista-modernista szociokulturális törésvonal mentén. A pártrendszer tagozódása is tükrözi ezeket a szociokulturális törésvonalakat. Az ötvenes évek első demokráciájában a pártpolitika radikalizálódásához és végső soron a demokratikus politikai rend összeomlásához vezetett a szekuláris és iszlám „blokkok" konfrontációja. Ugyanakkor a posztszuhartói korszakban a parlamenti politizálás kormányzati-ellenzéki dichotómiája már nem ezek mentén a törésvonalak mentén alakul. A jelenlegi kormánykoalícióban például szekuláris, 
tradicionalista és modernista muszlim pártok egyaránt részt vesznek és a politikai ellenzék ideológiai profilja hasonlóan vegyes képet mutat.

Elemzők szerint a jelenlegi iszlamista pártok közül a 2019-es választásokon a tradicionalista PKB és a modernista PKS parlamentbe jutása továbbra is lényegében biztosra vehető. Ugyanakkor a belső küzdelmekben meggyengült PPP és a karizmatikus alapító Raisz professzor távozása óta zsugorodó népszerúségú PAN parlamentbe kerülése, a 4\%-osra emelt bejutási küszöb mellett, legalábbis erősen kétséges. ${ }^{19}$ Mindenesre egy tradicionalista és egy karakteresen modernista muszlim párt 2019 után is minden bizonnyal jelen lesz az indonéz törvényhozásban.

Nézetünk szerint egy sajátságosan indonéz, de bizonyos nyugati előképektől mégsem idegen „konszenzusorientált" demokrácia modell van tehát kiformálódóban, ahol a politikai iszlám és az iszlamista pártok nem destabilizáló faktorként, éppen ellenkezőleg - számos „nyugati” kereszténydemokrata párthoz hasonlóan - a demokratikus konszenzust erősítő „muszlim demokrata” erőként vannak jelen.

Ehelyütt szeretném köszönetemet kifejezni a Budapesti Gazdasági Egyetem Keleti Üzleti Akadémiájának, valamint a jogjakartai Gadjah Mada Egyetem Társadalom és Politikatudományi Kara, valamint Nemzetközi Kapcsolatok Tanszékének. A KÜAK kutatói ösztöndíjprogramja és a Gadjah Mada Egyetem, mint fogadóintézmény munkatársainak értékes szakmai segítsége nélkül ez a tanulmány aligha születhetett volna meg. A Gadjah Mada Egyetem oktatói és kutatói közül név szerint mindenképpen köszönet illeti Nur Rachmat Yuliantoro professzort, a Nemzetközi Kapcsolatok Tanszék vezetőjét, Riza Noer Arfani professzor urat, a Nemzetközi Tanulmányok kutatóközpont igazgatóját, dr. Siti Mutiah Setiawatit és Muhammad Rumot a Nemzetközi Kapcsolatok Tanszék oktatóit, dr. Wawan Masudi politológust, a Társadalom és Politikatudományi kar kutatóját, valamint dr. Muhammad Najib Azcát a Biztonságpolitikai és Békekutatások Központjának szakértőjét. A velük folytatott beszélgetések és interjúk nagyban hozzájárultak ennek a kutatásnak az eredményeihez. A tanulmány esetleges hiányosságaiért ugyanakkor a felelősség kizárólag a szerzőt terheli.

\section{RÖVIDÍTÉSEK JEGYZÉKE}

Gerakan - Gerakan Indonesia Raya (Nagy Indonéziáért Mozgalom)

GOLKAR - Golongan Karya (Funkcionális Csoportok)

Hanura - Partai Hati Nurani Rakyat (Népi Öntudat Pártja)

ICMI - Ikatan Cendekiawan Muslim Se-Indonesia

(Muszlim Értelmiségiek Társasága)

Masyumi - Sujra Muslimin Indonesia

(Indonéziai Muszlim Felszabadítási Tanács) 


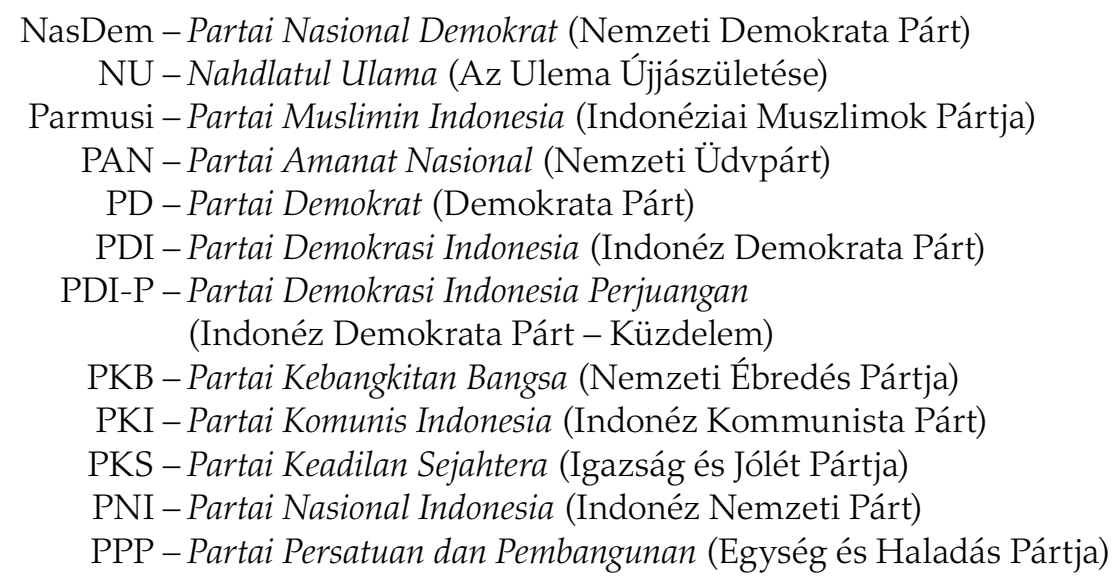

\section{JEGYZETEK}

1 Indonéziában a 2002-es alkotmánymódosítások vezették be a közvetlen, nép általi elnökválasztás intézményét, ezzel az ország kormányformája teljességgel prezidenciális jellegủ lett. Az első közvetlen elnökválasztásokat 2004-ben tartották a parlamenti választásokkal egy időben (Ufen, 2018: 308.).

2 A demokrácia fogalmának procedurális meghatározásakor Robert A. Dahl klasszikus poliarchiamodelljének kritériumait tartjuk szem előtt, úgy mint szabad és többpárti választások, intézményes hatalommegosztás, a média pluralizmusa stb. Ehhez még Samuel P. Huntington nyomán hozzátehetjük, hogy sikeres demokratikus konszolidációról akkor beszélhetünk, ha legalább két egymást követő szabad és többpárti választáson zökkenőmentes hatalomátadás valósul meg. Ez pedig Indonéziában a 2004-es választások nyomán teljesült (Huntington, 1992.).

3 Ez utóbbi a pesantren maláj szóbol ered, amely muszlim vallási iskolát jelent. A santri eredeti jelentése muszlim vallási iskolában tanuló diák (Hisyam, 2002: 302.).

4 Az iszlám fundamentalisták legfőbb célja a vallás megtisztítása az idők során „rárakódott”, ám annak eredeti szellemével össze nem férő újításoktól (bídá), lényegében tehát a Mohamed próféta és a négy „igaz” kalifa korának általuk tételezett eredeti, „tiszta” iszlámjához való visszatérés. A fundamentalizmus fogalmát gyakran azonosítják a politikai iszlamizmussal, holott ez utóbbi egy politikai ideológia. A politikai iszlám - avagy rövidebben iszlamizmus - központi gondolata az iszlám vallás tanításaira, pontosabban az iszlám vallásjogra a saríára - még pontosabban ennek az iszlamisták által adott értelmezésére - alapozott társadalom és politikai rendszer létrehozása. A modernkori politikai iszlám képviselői rendszerint vallási fundamentalisták is egyben, ugyanakkor a fundamentalizmus nem feltétlenül rendelkezik politikai töltettel (Naumkin, 2005: 235.).

5 Az indonéz szigetvilág demográfiai súlypontja hagyományosan a rendkívül termékeny Jáva szigete volt. Így a domináns etnikum az ún. jávai, akik a modern Indonézián belül a népesség körülbelül 40\%-át teszik ki és főleg Közép-, illetve Kelet-Jáván koncentrálódnak. A második leg- 
nagyobb lélekszámú etnikum az ún. szundai, akik főleg Nyugat-Jávát népesítik be, az ő arányuk ma körülbelül 15\% (Aspinall, 2011: 292.).

6 Clifford Geertz-et idézi Andreas Ufen. A holland társadalom politikai tagozódását a huszadik század jórészében ugyancsak felekezeti alapú szubkultúrák (liberális-szekuláris, fundamentalista-protestáns, katolikus) határozták meg (Ufen, 2008b: 9.).

7 A Pancasila, az öt alapelv: 1. Hit egy Istenben; 2. Emberiesség; 3. Nacionalizmus, mely Indonézia egységében fejeződik ki; 4. Demokrácia; 5. Szociális igazságosság (Hefner, 2000: 42.).

8 Ezek a muszlim, hindu, buddhista, konfuciánus és katolikus, illetve protestáns keresztény. A vallásfelekezetet az állampolgárok személyi igazolványában is feltüntetik. Noha annak megvan a lehetősége, hogy az igazolványon a vonatkozó rubrikát üresen hagyják, de senki nem vallhatja magát hivatalosan ateistának. 2009 Report on International Religious Freedom - Indonesia. United States Department of State, https://www.refworld.org/docid/4ae861361d.html 10.26. 2009.

9 A tiltakozások kapcsán ki kell emelnünk a demokratikus iszlám szervezetek szerepét, köztük mindenekelőtt az újra aktivizálódó Nahdlatul Ulamáét, amely 1984-ben szakított az addigi „hivatalos" iszlám ellenzékkel a PPP-vel (Barton, 2003: 486.; Ufen 2008b: 14.). Elnöke a nagy tekintélyú Abdurrahman Wahid professzor, a Szuharto rezsim demokratikus ellenzékének egyik vezető figurájává vált.

${ }^{10}$ A pártok effektív száma egy pártrendszerben Laakso és Taagepera formulája szerint: 1 osztva a pártok szavazatarányának tizedestörtben kifejezett (pl. 50\% = 0,5) értékeinek négyzetének öszszegével. A parlamenti pártok effektív számát a parlamentbe jutó pártok mandátumarányaiból számítjuk hasonló módon (Laakso-Taagepera, 1979).

${ }^{11}$ Az persze, hogy a PPP mennyiben tekinthető „modernista” muszlim pártnak, vitatható. Ne feledjük a pártot az 1970-es évekbern adminisztratív kényszer útján hozták létre a modernista Parmusi és a tradicionalista NU fúziójával. Bár a pártot sokan elsősorban a Masyumi örökésének tartják, valójában mély megosztottság jellemzi egy tradicionalista és modernista szárny által. Az utóbbi években a pártvezetésben a tradicionalista irányzat kerekedett felül (a szerző interjúja Dr. Wawan Masudival és Dr. Muhammad Najib Azcával, a Gadjah Mada Egyetem Társadalom és Politikatudományi Karának, illetve biztonságpolitikai és békekutatások Központja szakértőivel).

${ }^{12}$ Azyurmadi Azra nyomán a politikai iszlám platfomján álló pártként definiálhatunk minden olyan politikai erôt, amelyek programjukban és egyéb hivatalos dokumentumaikban kifejezetten az iszlámra, mint ideológiai alapra hivatkoznak - az említett magpártok közül a PPP és a PKS ilyennek tekinthető - vagy, bár hivatalosan a Pancasila ideológiai alapjára helyzkednek, de széleskörben használnak iszlám vallási szimbólumokat, muszlim társadalmi szervezetekhez kötődnek, és a társadalmi, illetve a politikai közmegegyezés is iszlám pártoknak tekinti őket, mint például a PKB-t vagy a PAN-t. (Azra, 2006: 41.)

${ }^{13}$ A szerző interjúja Farouk Alwynivel, a PKS párt Külkapcsolati Irodájának vezetőjével.

${ }^{14}$ Ez alól a szabályozás alól egyedül Aceh tartomány élvez kivételt, ahol a szeparatista lázadószervezetekkel kötött 2005-ös békemegállapodás értelmében múködhetnek a regionális pártok (Ufen, 200ba: 16.).

${ }^{15}$ A PDI-P esetében ilyennek tekinthető Megawati Sukarnoputri; a tradicionalista PKB-t tekintve a reformasi időszakában mindenképpen ilyen volt a 2009-ben elhunyt Abdurrahman Wahid 
professzor; a PAN pedig Amien Rais köré szerveződött, aki Wahidhoz hasonló értelmiségi/akadémiai háttérrel rendelkezett. Rais a yogyakartai Gadjah Mada Egyetem politikatudományi professzora volt, talán ez is magyarázza pártja kiugró népszerűségét Yogyakarta körzetében (a szerző interjúja Dr. Muhammad Najib Azcával).

${ }^{16}$ A szerző interjúja Farouk Alwynivel, a PKS párt Külkapcsolati Irodájának vezetőjével.

${ }^{17}$ A szerző interjúja Dr. Muhammad Najib Azcával és Dr. Wawan Masudival. „Prabowo Subianto to run for 2019 Indonesian presidential election with Jakarta deputy governor." The Straits Times, https://www.straitstimes.com/asia/se-asia/prabowo-subianto-says-to-run-again-for-indonesianpresident-in-2019-election. 10. 08. 2018.

${ }^{18}$ Amin az Indonéz Ulema Tanács nevű befolyásos iszlamista szervezet vezetője, akinek neve annak kapcsán vált országosan ismertté, amikor a tavalyi jakartai kormányzóválasztási kampány során a kínai és keresztény hátterú - egyébként eredetileg Jokowi és a PDI-P által is támogatott - Basuki Tjahaja Purnama kormányzójelöltet istenkáromlással vádolta meg. A botrány végül is a megválasztott kormányzó lemondásához vezetett (Dewi, 2018).

${ }^{19}$ A szerző interjúja Dr. Muhammad Najib Azcával és Dr. Wawan Masudival.

\section{IRODALOM}

2009 Report on International Religious Freedom - Indonesia. United States Department of State https://www.refworld.org/docid/4ae861361d.html 10.26. 2009.

Abdulbaki, Louay (2008): Democratisation in Indonesia: From Transition to Consolidation. Asian Journal of Political Science, Vol. 16, No. 2, August, 151-172. https://doi.org/10.1080/02185370802204099. Aspinall, Edward (2011): Democratization and Ethnic Politics in Indonesia: Nine Theses. Journal of East Asian Studies, Vol. 11, No. 2, May-August, 289-319. https://doi.org/10.1017/s159824 0800007190.

Azra, Azyumadi (2002): Globalization of Indonesian Muslim Discourse. In Johan Meuelman (ed.): Islam in the Era of Globalization. London-New York, Routledge-Curzon.

Azra, Azyumadi (2006): Indonesia, Islam, and Democracy: Dynamics in a Global Context. Equiox Publishing.

Barton, Greg (2010): Indonesia: Legitimacy, Secular Democracy and Islam. Politics \& Policy, Vol. 38, No.3, 471-496. https://doi.org/10.1111/j.1747-1346.2010.00244.x.

Bertrand, Jacques (2003): Nationalism and Ethnic Conflict in Indonesia. Cambridge University Press. https://doi.org/10.1017/cbo9780511559341.

Buehler, Michael (2009) : Islam and Democracy in Indonesia. Insight Turkey, Vol. 11. No. 4, 51-63.

Dewi, Sita W. (2018): Who is Ma'ruf Amin, Jokowi's running mate? The Jakarta Post, http://www. thejakartapost.com/news/2018/08/09/who-is-maruf-amin-jokowis-running-mate.html?src=mostvie wedEpg=news/2018/05/13/jakarta-east-java-riau-islands-on-highest-alert-after-surabaya-bombings. html. 09. 08. 2018.

Eliraz, Giora (2004): Islam in Indonesia. Brighton-Portland, Sussex Academic Press. https://doi. org/10.1093/jis/etl037. 
Fionna, Ulla-Tomsa, Dirk (2017): Parties and Factions in Indonesia: The Effects of Historical Legacies and Institutional Engineering. ISEAS Working Papers.

Fukuoka, Yuki (2013): Oligarchy and Democracy in Post-Suharto Indonesia. Political Studies Review, Vol. 11, No. 1, 52-64. https://doi.org/10.1111/j.1478-9302.2012.00286.x.

Hefner, Robert W. (2000): Civil Islam. Princeton-Oxford, Princeton University Press. https://doi. org/10.1515/9781400823871.

Higashikata, Takayuki-Kawamura, Koichi (2015): Voting Behaviour in Indonesia from 1999 to 2014. Religious Cleavage or Economic Performance? Institute of Developing Economies, Working Paper No. 512. https://doi.org/10.2139/ssrn.2620455.

Hosen, Nadirsyah (2005): Religion and the Indonesian Constitution: A Recent Debate. Journal of Southeast Asian Studies, Vol. 36. No. 3, 419-440. http://dx.doi.org/10.1017/S0022463405000238

Huntington, Samuel P. (1991): The Third Wave: Democratization in the Late Twentieth Century. University of Oklahoma Press.

Laakso, Maarku-Taagepera, Rein (1979): Effective Number of Parties. A Measure Application to West Europe. Comparative Political Studies. Vol 12, No. 1, 3-27. https://doi.org/10.1177/0010 41407901200101.

Meuelman, Johan (2002): South-East Asian Islam and the Globalization Process. In: Johan Meuelman (ed.): Islam in the Era of Globalization. London-New York, Routledge-Curzon.

Mietzner, Marcus (2008): Comparing Indonesia's party systems of the 1950s and the post-Suharto era: from centrifugal to centripetal interparty competition. Journal of Southeast Asian Studies, Vol. 39. Issue 3, 431-453. https://doi.org/10.1017/s0022463408000337.

Mietzner, Marcus (2012): Indonesia's democratic stagnation: anti-reformist elites and resilient civil society. Democratization, Vol. 19, No. 2, April, 209-229. https://doi.org/10.1080/13510347.2011. 572620

Mietzner, Marcus-Aspinall, Edward (2010): Problems of Democratisation in Indonesia: an Overview. In: Marcus Mietzner-Edward Aspinall (eds.): Problems of Democratisation in Indonesia. ISEAS - Yusof Ishak Institute. https://doi.org/10.1355/9789814279918-006.

Mietzner, Marcus (2016): Coercing Loyalty: Coalitional Presidentialism and Party Politics in Jokowi's Indonesia. Contemporary Southeast Asia: A Journal of International and Strategic Affairs. Vol. 38; No. 2, 209-232.

Nakamura, Mitsuo (2005): Islam and Democracy in Indonesia: Observations on the 2004 General and Presidential Elections. Cambridge, Islamic Legal Studies Program, Harvard Law School.

Naumkin, Vitalij (2005): Radical Islam in Central Asia: Between Pen and Rifle. Lanham, Rowman \& Littlefield Publishers.

Prabowo Subianto to run for 2019 Indonesian presidential election with Jakarta deputy governor. The Straits Times, https://www.straitstimes.com/asia/se-asia/prabowo-subianto-says-to-run-againfor-indonesian-president-in-2019-election 2018. október 18.

Rabasa, Angel-Haseman, John (2002): The Military and Democracy in Indonesia: Challenges, Politics and Power. RAND - National Security Division.

Robison, Richard-Hadiz, Vedi R. (2004): Reorganising Power in Indonesia: The Politics of Oligarchy in an Age of Markets. London-New York, Routledge. https://doi.org/10.4324/9780203401453. 
Sulistyo, Hermawan (2002): Electoral Politics in Indonesia: A Hard way to Democracy. In: Aurel Croissant (ed.): Electoral Politics in Southeast and East Asia. Singapore, Friedrich Ebert Stiftung, Office for Regional Co-Operation in Southeast Asia.

Tanthowi, Pramono U. (2012): Religiosity, parties and democratization in post-Soeharto Indonesia. Indonesian Journal of Islam and Muslim Societies, Vol. 2. No. 1, June, 1-27. https://doi.org/10.18326/ ijims.v2i1.1-27.

Ufen, Andreas (2008a): The Evolution of Cleavages in the Indonesian Party System. German Institute of Global and Area Studies, Working Paper 74. https://doi.org/10.2139/ssrn.1123942.

Ufen, Andreas (2008b): From aliran to dealignment: political parties in post-Suharto Indonesia. South-East Asia Research, Vol. 16, No. 1, 5-41. https://doi.org/10.5367/000000008784108149.

Ufen, Adreas (2018): Party presidentialization in post-Suharto Indonesia. Contemporary Politics, Vol. 24, Nr. 3, 306-324. https://doi.org/10.1080/13569775.2017.1413499.

Wanandi, Jusuf (2002): Islam in Indonesia: Its History, Development and Future Challenges. AsiaPacific Review, Vol. 9, No. 2, 104-112. http://dx.doi.org/10.1080/1343900022000036115.

Woodward, Mark (2008): Indonesia's Religious Political Parties: Democratic Consolidation and Security in Post-New Order Indonesia. Asian Security, Vol. 4, Nr. 1, 41-60. https://doi.org/10. 1080/14799850701783197 